UDK 582.475:582.728.4(497.6)

$630 * 44: 582.475(497.6)$

\title{
THE INTENSITY OF INFECTION OF STEM SILVER FIR Abies alba Mill. BY WHITE MISTLETOE Viscum album L. ON BOSNIA AND HERZEGOVINA AREA
}

\section{Intenzitet zaraženosti stabala jele Abies alba Mill. bijelom imelom Viscum album L. na području Bosne i Hercegovine}

Osman Mujezinović ${ }^{1}$, Tarik Treštić ${ }^{1}$, Azra Čabaravdić ${ }^{1}$ and Mirza Dautbašić ${ }^{1}$

\begin{abstract}
In terms of the health status, in Bosnia and Herzegovina, European silver fir (Abies alba) is currently most threatenedby the white mistletoe (Viscum album ssp. abietis).Along with drought and pollution, white mistletoe infestation plays an important role in silver fir decline.

The aim of this research was to determine the intensity of infestation of European silver fir trees by the white mistletoe.

In order to realise the defined aim, two compartments were chosen in the area of Forest Management Association of Zenica-Doboj Canton and Forestry Office "Olovo" where the analysis of the presence of mistletoe was conducted.

In total, 451 fir trees were examined and an assessment of the intensity of infested trees was carried out by implementation of Hawksworth Index of Infestation. According to the results conducted by the research, it was determined that the intensity of infestation of European fir stands differed according to the thirds of crown of the tree. Significant differences were also found in the severity of mistletoe intensity on trees of host trees within the diameter classess. A large number of mistletoe shrubs further deplete the host tree, making it more susceptible to secondary attacks by harmful insects and pathogens.
\end{abstract}

Key words:European silver fir, mistletoe, intensity presence of shrubs, third treecrown, diameter class, health status.

\section{INTRODUCTION - Uvod}

European silver fir is one of the most widespread conifer species in Bosnia and Herzegovina, covering around 652.237 ha (STEFANOVIĆ, ET AL.,1983). Its health status are influenced by numerous factors of an abiotic and biotic nature.

\footnotetext{
${ }^{1}$ Faculty of Forestry, University of Sarajevo
} 
White mistletoe - Viscum album ssp. abietis (Wiesb.). Abromeit is the main destabilising factor in the trees of silver fir (DIMINIĆ, ET AL., 2011; MUJEZINOVIĆ, 2007; IDŽOJTIĆ, 2005; IDŽOJTIĆ, 2003).The infestation intensity of this semi-parasite plant in the forest area in $\mathrm{BiH}$ is in continual rise. Contributing factors to this are decade-long errors in managing and underestimating the actual role of mistletoe (USČUPLIĆET AL., 2007; USČUPLIĆ, 1992).

Harmful effects of this semi-parasitic plant are multiple. By establishing a functional endophytes system using water and minerals from the vasculatory system, it influences the fall of the water potential of the fir. The total daily transpiration of mistletoe is three-times larger than the plant hosts (ZUBER, 2003). The harmful role of mistletoe on fir trees also represent: the decreasing in size of the assimilation area, concentration of mistletoe shrubs in the upper part of the crown of the tree swhich lead to the decrease in their fructification, directly affecting the fir renewal by reducing the seed vitality (BALLIAN, 2013), any severe infestation is frequently associated with premature dieback of host trees, negatively affecting the quantity and quality of wood, reducing the plant hosts vitality and predispositioning them toother harmful agents (UČUPLIĆ ET AL., 2008; MUJEZINOVIĆ, 2007; TSOPELAS, 2004; NOETZLI ET AL., 2003; UsČUPLIĆ, 1992; KLEPAC,1955).

With the increased number of mistletoe shrubs, the level of fir defoliation rises (DIMINIĆ ET AL., 2011), but reduces the increment diameter of the trees (MUJEZINOVIĆ, 2007).

The aim of this study is to determine the intensity of infection of fir trees by this semi-parasitic plant.

\section{MATERIAL AND RESEARCH METHODS - Materijal i metode istraživanja}

Research objects are found on the Forest Management Association of ZenicaDoboj Canton and Forestry Office "Olovo" which belong to management area "Tribija - Duboštica". Assessment of the intensity of infestation of the European fir stands was conducted in two localities. The first locality was Sokolina, compartment 1 , whose stands belongs to the management class 1204 - The forests of beech and fir with spruce in predominantly shallow calcareous terrains. The second locality was SuhaVojnica, compartment 181, management class 1231 - The forests of beech and fir with spruce in predominantly deep terrain on peridotite.

Data was collected from trees that were found on representative surfaces chosen through a systematic pattern. The elementary surface specimen was - "test circuits" which were systematically arranged on the ground in a100 m x $100 \mathrm{~m}$ squared netting. Each elementary surface specimen was composed of six concentric circles of different radii that enabled a selective choice of stands in the sample.

The intensity of the presence of white mistletoe on European silver fir trees was assessed by implementation of Hawksworth Index of Infestation (HAWKSWORTH 
AND SCHARPF, 1986). On the basis of this method, the tree of crown of infested stands were divided into thirds. Infestation index 1 was appointed to the part of the tree of crown where mistletoe was inherent on less than a half of the branch total. If the presence of shrubs in the onlooked third tree of crown was more than half of the branch total, the incursion intensity would be marked with 2. Summing up points for all the thirds gives us an overall intensity of infestation.

After completing the measurements of individual parameters, a statistical set was arranged by classifying individual elements after which the analysis and data processing was carried out (programme SPSS 12,0; SPSS Inc.).

\section{RESULTS - Rezultati}

Research intensity of infestation of European silver fir was conducted on example of 451 trees.

The structure of infested and uninfested trees of European silver fir on area of assessment are shown in tables 1 i 2.

Table 1: The structure of number trees of fir in compartment 1., management area „TribijaDuboštica“"

Tabela 1: Raspodjela broja stabala jele u odjeljenju 1., G.J. „,Tribija-Duboštica“

\begin{tabular}{|l|c|c|c|c|c|c|}
\hline \multirow{2}{*}{$\begin{array}{l}\text { Health status } \\
\text { of trees }\end{array}$} & $5-10$ & $10-20$ & $20-30$ & $30-50$ & $50-80$ & \multirow{2}{*}{$\begin{array}{c}\text { Total } \\
\text { number of } \\
\text { trees } \\
\text { /ha }\end{array}$} \\
\cline { 2 - 6 } & \multicolumn{7}{|c|}{ Number trees per ha } & 43,0 \\
\hline Infested trees & 0,0 & 0,0 & 7,5 & 29,8 & 5,7 & 403,5 \\
\hline $\begin{array}{l}\text { Uninfested } \\
\text { trees }\end{array}$ & 131,0 & 179,6 & 64,7 & 28,0 & 0,2 & 446,5 \\
\hline Total & 131,0 & 179,6 & 72,2 & 57,8 & 5,9 & 4 \\
\hline
\end{tabular}

Table 2. The structure of number trees of fir in compartment 181., management area „TribijaDuboštica“"

Tabela 2. Raspodjela broja stabala jele u odjeljenju 181., G.J. ,,Tribija-Duboštica“

\begin{tabular}{|l|c|c|c|c|c|c|}
\hline \multirow{2}{*}{$\begin{array}{l}\text { Health status } \\
\text { of trees }\end{array}$} & \multicolumn{7}{|c|}{ Diameter class } & \multirow{2}{*}{$\begin{array}{c}\text { Total } \\
\text { number of } \\
\text { trees } \\
\text { /ha }\end{array}$} \\
\cline { 2 - 6 } & $5-10$ & $10-20$ & $20-30$ & $30-50$ & $50-80$ & 95,3 \\
\hline Infested trees & 0,0 & 15,4 & 33,0 & 45,5 & 1,4 & 9 \\
\hline $\begin{array}{l}\text { Uninfested } \\
\text { trees }\end{array}$ & 59,9 & 114,0 & 57,8 & 13,1 & 0,0 & 244,8 \\
\hline Total & 59,9 & 129,4 & 90,8 & 58,6 & 1,4 & 340,1 \\
\hline
\end{tabular}

The structure trees of fir according to the total index of infestation are shown in tables 3 i 4 . 
Table 3. The structure of number infested of trees fir according to the total index of infestation (compartment 1., management area „Tribija-Duboštica“)

Tabela 3. Raspodjela broja zaraženih stabala jele prema ukupnom indeksu zaraženosti (odjeljenje1., GJ „, Tribija-Duboštica“)

\begin{tabular}{|c|c|r|r|r|r|r|r|}
\hline \multirow{2}{*}{$\begin{array}{c}\text { Diameter } \\
\text { class }\end{array}$} & \multicolumn{7}{|c|}{ Index of infestation } \\
\cline { 2 - 8 } & 0 & 1 & 2 & 3 & 4 & 5 & 6 \\
\hline $5,0-9,9$ & 18 & 0 & 0 & 0 & 0 & 0 & 0 \\
\hline $10,0-19,9$ & 80 & 0 & 0 & 0 & 0 & 0 & 0 \\
\hline $20,0-29,9$ & 43 & 3 & 2 & 0 & 0 & 0 & 0 \\
\hline $30,0-49,9$ & 50 & 14 & 28 & 8 & 2 & 0 & 1 \\
\hline $50,0-79,9$ & 1 & 1 & 8 & 4 & 3 & 9 & 3 \\
\hline TOTAL & 192 & 18 & 38 & 12 & 5 & 9 & 4 \\
\hline
\end{tabular}

Table 4: The structure of number infested of trees fir according to the total index of infestation (compartment 181., management area „Tribija-Duboštica“)

Tabela 4: Raspodjela broja zaraženih stabala jele prema ukupnom indeksu zaraženosti (odjeljenje 181., GJ „, Tribija-Duboštica“)

\begin{tabular}{|c|c|c|c|c|c|c|c|}
\hline \multirow{2}{*}{$\begin{array}{c}\text { Diameter } \\
\text { class }\end{array}$} & \multicolumn{7}{|c|}{ Index of infestation } \\
\cline { 2 - 8 } & 0 & 1 & 2 & 3 & 4 & 5 & 6 \\
\hline $05,0-09,9$ & 6 & 0 & 0 & 0 & 0 & 0 & 0 \\
\hline $10,0-19,9$ & 37 & 2 & 1 & 2 & 0 & 0 & 0 \\
\hline $20,0-29,9$ & 28 & 6 & 3 & 2 & 4 & 1 & 0 \\
\hline $30,0-49,9$ & 17 & 14 & 13 & 12 & 10 & 9 & 1 \\
\hline $50,0-79,9$ & 0 & 3 & 0 & 2 & 0 & 0 & 0 \\
\hline TOTAL & 88 & 25 & 17 & 18 & 14 & 10 & 1 \\
\hline
\end{tabular}

The structure of number trees of fir according to index of infestation in assessed parts of crown are shown in tables $5 \mathrm{i} 6$.

Table 5: The structure of number of infested trees of fir according to the index of infestation in assessed parts of crown (compartment 1., management area „Tribija-Duboštica“)

Tabela 5: Raspodjela broja zaraženih stabala jele prema indeksu zaraženosti u analiziranim dijelovima krošnje (odjeljenje 1., GJ ,,Tribija-Duboštica“)

\begin{tabular}{|c|c|c|c|c|c|c|c|c|c|}
\hline \multirow{4}{*}{$\begin{array}{l}\text { Diameter } \\
\text { class }\end{array}$} & \multicolumn{9}{|c|}{ Index of infestation } \\
\hline & \multicolumn{3}{|c|}{ Upper part of crown } & \multicolumn{3}{|c|}{ Middle part of crown } & \multicolumn{3}{|c|}{ Lower part of crown } \\
\hline & 0 & 1 & 2 & 0 & 1 & 2 & 0 & 1 & 2 \\
\hline & \multicolumn{9}{|c|}{ Number of trees } \\
\hline $05,0-09,9$ & 0 & 0 & 0 & 0 & 0 & 0 & 0 & 0 & 0 \\
\hline $10,0-19,9$ & 0 & 0 & 0 & 0 & 0 & 0 & 0 & 0 & 0 \\
\hline $20,0-29,9$ & 2 & 3 & 0 & 2 & 3 & 0 & 4 & 1 & 0 \\
\hline $30,0-49,9$ & 6 & 38 & 9 & 17 & 32 & 4 & 41 & 11 & 1 \\
\hline $50,0-79,9$ & 0 & 12 & 16 & 1 & 13 & 14 & 12 & 13 & 3 \\
\hline TOTAL & 8 & 53 & 25 & 20 & 48 & 18 & 57 & 25 & 4 \\
\hline
\end{tabular}


Table 6: The structure of number of infested trees of fir according to the index of infestation in assessed parts of crown (compartment 181., management area „Tribija-Duboštica“)

Tabela 6: Raspodjela broja zaraženih stabala jele prema indeksu zaraženosti u analiziranim dijelovima krošnje (odjeljenje 181., GJ ,Tribija-Duboštica“)

\begin{tabular}{|c|c|c|c|c|c|c|c|c|c|}
\hline \multirow{4}{*}{$\begin{array}{l}\text { Diameter } \\
\text { class }\end{array}$} & \multicolumn{9}{|c|}{ Index of infestation } \\
\hline & \multicolumn{3}{|c|}{ Upper part of crown } & \multicolumn{3}{|c|}{ Middle part of crown } & \multicolumn{3}{|c|}{ Lower part of crown } \\
\hline & 0 & 1 & 2 & 0 & 1 & 2 & 0 & 1 & 2 \\
\hline & \multicolumn{9}{|c|}{ Brojstabala } \\
\hline $05,0-09,9$ & 0 & 0 & 0 & 0 & 0 & 0 & 0 & 0 & 0 \\
\hline $10,0-19,9$ & 2 & 2 & 1 & 3 & 0 & 2 & 3 & 2 & 0 \\
\hline $20,0-29,9$ & 4 & 4 & 8 & 6 & 6 & 4 & 10 & 6 & 0 \\
\hline $30,0-49,9$ & 6 & 20 & 33 & 14 & 30 & 15 & 39 & 19 & 1 \\
\hline $50,0-79,9$ & 0 & 4 & 1 & 3 & 2 & 0 & 4 & 1 & 0 \\
\hline TOTAL & 12 & 30 & 43 & 26 & 38 & 21 & 56 & 28 & 1 \\
\hline
\end{tabular}

On the basis of the stastical analysis several differences have been determined in the average index rate of infestation of the fir trees, depending on the diameter growth in degrees and the of parts of their tree of crown. The analyses were conducted using the Univariate Analysis of Varianse (SPSS 12) method. The significance in the differences was tested by using the Tukey HSD test. The stastistical analysis results are shown in table 7.

Table 7: Average index of infestation of trees to depending by diameter class

Tabela 7: Prosječni indeks zaraženosti stabala u ovisnosti od debljinske klase

\begin{tabular}{|c|c|c|c|c|}
\hline \multicolumn{2}{|c|}{ Diameter class } & Mean difference & \multirow{2}{*}{ Standard error } & $\begin{array}{c}\text { Significance of } \\
\text { difference }\end{array}$ \\
\hline \multirow{3}{*}{$(\mathrm{A})$} & $(\mathrm{B})$ & $(\mathrm{A}-\mathrm{B})$ & & \\
\hline \multirow{3}{*}{$05,0-09,9$} & $10,0-19,9$ & $-0,0820$ & 0,27372 & 0,998 \\
\cline { 2 - 5 } & $20,0-29,9$ & $-0,5000$ & 0,28096 & 0,387 \\
\cline { 2 - 5 } & $30,0-49,9$ & $-1,5363(*)$ & 0,26646 & 0,000 \\
\cline { 2 - 5 } & $50,0-79,9$ & $-3,3235(*)$ & 0,32680 & 0,000 \\
\hline \multirow{3}{*}{$10,0-19,9$} & $20,0-29,9$ & $-0,4180$ & 0,16926 & 0,099 \\
\cline { 2 - 5 } & $30,0-49,9$ & $-1,4543(*)$ & 0,14391 & 0,000 \\
\cline { 2 - 5 } & $50,0-79,9$ & $-3,2416\left(^{*}\right)$ & 0,23772 & 0,000 \\
\hline \multirow{2}{*}{$20,0-29,9$} & $30,0-49,9$ & $-1,0363(*)$ & 0,15725 & 0,000 \\
\cline { 2 - 5 } & $50,0-79,9$ & $-2,8235(*)$ & 0,24602 & 0,000 \\
\hline $30,0-49,9$ & $50,0-79,9$ & $-1,7872(*)$ & 0,22932 & 0,000 \\
\hline
\end{tabular}




\section{DISCUSSION - Diskusija}

Research on the intensity of infestation of stands by white mistletoe, which is the subject of this paper, was conducted in the area of Forest Management Association of Zenica-Doboj Canton and Forestry Office "Olovo". For the analysis of this impact, two spatially distanced compartments were chosen, in management area "Tribija Dubotica" having different geological substrates. By a systematic selection and measurement 451 fir trees were encompassed.

In compartment 1, 278 fir stands were examined. On 86 stands $(31 \%)$ the presence of mistletoe was established with a varying intensity. Mistletoe shrubs had already been indentified in the $20-30 \mathrm{~cm}$ diameter class; whereas in the $30-50 \mathrm{~cm}$ class the intensity of infestation was as such that the number of infected stands was higher than those of healthy fir stands (table 1). The 50-80 cm diameter class had almost no stands that were not infested by mistletoe shrubs. Tree of crown of these stands received more sun enabling a faster development of mistletoe shrubs (NOETZLI ET AL., 2003).

Measurement and assessment in compartment 181 encompassed 150 fir stands. The intensity and emersion of mistletoe in this facility was higher than in the previous one. Yet $78 \%$ of stands with a breast diameter above $30 \mathrm{~cm}$ were infested by mistletoe (table 2).

According to the diameter at breast height, the analysed stands were catagorised into five (5) classes. This approach enabled the drawing of conclusions of the appearance and intensity of mistletoe on tree of crown in accordance of the diameter at breast height. For a detailed analysis of the infested stands and a more precise overview of the effect of mistletoe on their health status, the intensity of infestation was evaluated for each of trees. The intensity of the presence of white mistletoe on European silver fir trees was assessed by implementation of Hawksworth Index of Infestation (HAWKSWORTH AND SCHARPF, 1986). With the application of this system, the intensity of infestation was evaluated on the basis of the apparition of mistletoe shrubs on three tree of crown parts and was collectively rendered for the analysed stand. A detailed overview of the intensity of infestation of fir is possible through a detailed examination of all the branches of cut trees (DIMINIĆ ET AL., 2011). However, the Hawksworth Index of Infestation also has a practical value upon evaluating which stands should be removed from the comprisement due to a high intensity of infestation and possible consequences with the binding of other biotic agents (USČUPLIĆ ET. AL., 2008; MUJEZINOVIĆ, 2007; TSOPELAS, 2004).

The intensity of infestation was analysed by diameter classes and parts of tree crown of the given trees (table 3-6).

The overall intensity of fir trees infestation indicate that the largest number of infested trees is found in the fourth and not the fifth diameter class. This arrangement of the trees is the result of cutting and removing trees that are in the final stage of their 
diameter degrees. Trees graded 2 on the infestation index prevail in the fourth diameter class.

The overview of trees infection along parts of tree of crown gives a better insight into the presence of mistletoe. The assessed facilities differ according to the presence of mistletoe in the lower third of the tree of crown. In compartment 1 , the most representative trees are those whose index level of infestation in the third tree of crown amount to one (1) (table 5), whereas in compartment 181 the most representative trees have an index level of two (2) (table 6). In the mid and upper third of the tree of crown, the infestation of trees in both sections is similar. Trees with the index level one (1) dominate in the mid third, while the majority of trees without this semi-parasitic plant are found in the upper third.

Compartment 1 , in terms of the portion of infestation on tree of crown show a certain regularity. Infestation of the same part of the tree of crown rises with the diameter growth of trees (diameter class) which may indicate to a gradual spreading of this semi-parasite and a "transferral" from higher to lower parts of the tree crown. In compartment 181 this regularity is disturbed presumably by the last cuttings. In this respect, it is indicative that the infestation level of the lower third part of tree of crown trees belonging to the fourth diameter class are significantly highly marked with index 2 alongside a stronger infestation level of the remaining tree of crown parts, while the infestation level of all other fifth class tree of crown are significantly lower.

The difference in the existence of infection in certain parts of tree of crown was also confirmed by the results of the statistical analysis. Statistically meaningful differences in the intensity of infection were determined among individual diameter classes. These differences were manifested between the first and fourth, and first and fifth diameter classe, then between the second and fourth, and second and fifth, and lastly between the third, fourth and fifth diameter class mutually (table 7). The reason for this is the increase in portion of infested trees in classes of thicker trees, which has already been mentioned (table $3-6$ ). This trend is understandable if on one hand one takes into account the co-relation between the height of fir trees and their breast diameter, and on the other hand the significance of light for the process of photosynthesis, growth, fruiting and mistletoe germination. A positive co-relation between the breast diameter of trees and the intensity of infection has also been cited by other authors (BARBU, 2010; NOETZLI ET AL., 2003). In principle, thicker stands are older which implys that they have been present in the components and thus significantly longer being exposed to possible semi-parasitic infestations.

In exteremely infested trees, mistletoe causes an uneconomic use of water resulting to their dehydration and gradual dieback. Exactly by detracting water and minerals, mistletoe primarily weakens the vitality of their host.Trees that have been heavily infested by mistletoe are susceptible to attacks by secondary biotic and abiotic damaging agents (USČUPLIĆ ET AL., 2008; MUJEZINOVIĆ, 2007).The primary harmful effects and other types of mistletoe that result in a reduction in vitality and general health decline of the host has been confirmed by other authors (TREŠTIĆ ET AL., 2006). 
That mistletoe represents a significant factor in the process of decline of trees thus significantly influencing the stability of components of fir has been confirmed by other authors (BALLIAN, 2013; BARBU, 2010; GLAVAŠ, 2012; TSOPELAS, 2004; UsČUPLIĆ ET AL., 2008).

\section{CONCLUSIONS - Zaključci}

These researches were aimed at determining the intensity of the occurrence of mistletoe on fir trees. For that purpose two research objects where chosen for analysing 451 fir trees (compartment 1 and 181, management area "TribijaDuboštica"). After the conducted analysis, the following was concluded:

- The presence of mistletoe was registered in both compartments, whereas the stonger infestation was recorded in compartment 181.

- The intensity of infestation differed in singular thirds of tree of crown. The largest number of trees having an infestation index (2) was registered in the lower third, while the largest number of trees without the presence of mistletoe (index 0) was found on the upper thirds of tree of crown. This health status is the the result of a gradual 'moving' of mistletoe from higher to lower tree parts of the infected stands.

- The intensity of infestation increase with the growth of the diameter at breast height.

\section{REFERENCES - Literatura}

BARBU, C. (2010): The incidence and distribution of white mistletoe (Viscum album ssp. abietis) on Silver fir (Abiesalba Mill.) stands from Eastern Carpathians. Ann. For. Res. 53 (1): 27-36.

BALLIAN, D. (2013): Genetic overload of silver fir (Abiesalba Mill.) from five populations from central Bosnia and Herzegovina. Folia ForestaliaPolonica, series A, 2013, Vol. 55 (2), $49-57$.

Diminić, D., РотOČıć, N., JAZBEC, A., ŽUPANIć, M. (2011): Zaraženost bijelom imelom i status ishrane obične jele u Gorskom Kotaru. Croat. J. For. Eng. 32 - 1: 223 237.

HAWSKWORTH. F. G., SCHARPF, R. F. (1986): Spread of European mistletoe (Viscum album) in California, U. S. A. Eur. J. For. Path.16: 1 - 64.

IdŽojtić, M., Glavaš, M., Zebec, M., Pernar, R., Bećarević, J., Glova, K., Pavlus, N. (2005): Zaraza obične jele (Abies alba Mill.) bijelom imelom (Viscum album L. ssp. Abietis /Wiesb./Abrom.) u Hrvatskoj. Śumarski list 129 (11-12): 559-573, Zagreb. 
Ižojtić, M., Pernar, R., Kauzlarić, M., Abramović, M., Janković, D., Pleše, M. (2003): Intenzitet zaraze obične jele (Abies alba Mill.) imelom (Viscum album L. ssp. abietis /Wiesb./Abrom.) na području Uprave šuma podružnica Delnice. Šumarski list 127 (11-12): 545-559, Zagreb.

KLEPAC, D. (1955): Utjecaj imele na prirast jelovih šuma. Šumarski list (7- 8): 231 244, Zagreb.

MuJEZINOVIĆ, O. (2007): Uticaj imele (Viscum album L.) na prirast jele (Abies alba M.) i ulančavanje drugih štetnih biotičkih agenasa. Magistarski rad. Šumarski fakultet Univerziteta u Sarajevu.

Noetzli, K. P., Muller, B., Sieber, T. N. (2003): Imact of population dynamics of white mistletoe (Viscum album ssp. abietis) on European silver fir (Abiesalba). Ann. For. Sci: 60: 773-779.

Stefanović, V., Beus, V., BurlicA, Č., Dizdarević, H., Vukorep.I. (1983): Ekološko vegetacijska rejonizacija Bosne i Hercegovine. Šumarski fakultet Univerziteta u Sarajevu. Posebno izdanje br. 17, Sarajevo.

TREŠTIĆ, T., DAUTBAŠıć, M., MuJEZINOVIĆ, O. (2006): Uticaj hrastove imele (Loranthus europaeus Jacq.) na stabilnost sastojina hrasta kitnjaka. Radovi Šumarskog fakulteta Univerziteta u Sarajevu. No. 1, 2006 (87 - 93). Sarajevo.

Tsopelas, P., Angelopoulos, A., Economou, A., Soulioti, N. (2004): Mistletoe (Viscum album) in the fir forest of Mount Parnis, Greece. Forest ecology and management, 202 (1-3): 59-65.

USČUPLIĆ, M., (1992): Uticaj sistema gazdovanja na pojavu imele. Glasnik Šumarskog fakulteta Univerziteta u Beogradu: 7-18, Beograd.

Usčuplić, M., Dautbašıć, M., Treštić, T., Selman, E., Mujezinović, O., Nišıć, T,.JoKanović, B. (2007): Bolesti i štetnici obične jele (Abiesalba Mill.) u Bosni i Hercegovini. Društvo za zaštitu bilja u Bosni i Hercegovini, 1-114, Sarajevo.

USČUPlić, M., TREŠtić, T., DAutBašıć, M., MuJezinović, O. (2008): Utjecaj bijele imele (Viscum album L. ssp. abietis /Wiesb./Abrom.) na bio masu iglica obične jele (Abies alba Mill.) Radovi Šumarskog institututa Jastrebarsko 43 (1): 31-37, Jastrebarsko.

ZUBER, D. (2003): Biological flora of Central Europe: Viscum album L. Flora 199: 181-203. 


\section{SAŽETAK}

Obična jela u Bosni i Hercegovini je najrasprostranjenija četinarska vrsta. Na njeno zdravstveno stanje utiču brojni faktori abiotske i biotske prirode. Međutim, u današnje vrijeme bijela imela je glavni destabilizirajući faktor njenog zdravstvenog stanja. Intenzitet napada ovog poluparazita u šumama području BiH je u stalnom porastu, čemu doprinose decenijske greške u gospodarenju i podcjenjivanje njene stvarne uloge. imelom.

Cilj ovog rada je utvrđivanje intenziteta zaraženosti stabala jele bijelom

Istraživanje intenziteta zaraženosti stabala jele provedeno je na području Šumsko - privrednog društva Zeničko - dobojskog kantona, Šumarija "Olovo", u dva odjeljenja 1 i 181 koji pripadaju gospodarskoj jedinici "Tribija - Duboštica".

Prikupljanje podataka je vršeno sa stabala koja su se nalazila na reprezentativnim površinama odabranim sistematskim uzorkom.

Intenzitet zaraženosti utvrđivan je prema metodi Hawskwort-a.

Ukupno je pregledano 451 stablo i to: u odjeljenju 1 (278) i odjeljenju 181 (150) stabala jele.

Analizirana stabla su prema prsnom prečniku razvrstana u pet (5) debljinskih klasa.

Ukupni intenzitet zaraženosti stabala ukazuje da se najveći broj zaraženih stabala jele nalazi u četvrtoj a ne petoj debljinskoj klasi. Ovakav raspored stabala je posljedica sječa kojima se redovito uklanjaju stabla završnog debljinskog stepena. U četvrtoj debljinskoj klasi preovladavaju stabla ocijenjena sa indeksom zaraženosti 2.

Postojanje razlika u intenzitetu zaraženosti stabala jele koja su bila svrstana $u$ različite debljinske klase potvrđeno je i statistički. Ove razlike su se ispoljile između prve i četvrte i prve i pete debljinske klase, potom između druge i četvrte i druge i pete i najzad treće, četvrte i pete debljinske klase međusobno (tabela 7).

Prikaz zaraženosti stabala po dijelovima krošnje daje bolji uvid u prisustvo imele. U odjeljenju 1, najzastupljenija su stabla čija veličina indeksa zaraženosti donje trećine krošnje iznosi jedan (1) (tabela 5), dok su u odjeljenju 181. najzastupljenija stabla sa indeksom dva (2) (tabela 6). U srednjoj i gornjoj trećini krošnje zaraženih stabala u oba odjeljenja prisustvo imele je slično. U srednjoj trećini dominiraju stabla sa indeksom jedan (1) dok u je gornjoj trećini najviše stabala bez pojave ove parazitske cvjetnice.

Odjeljenje 1, u pogledu zaraženosti dijelova krošnje pokazuje izvjesnu pravilnost. Zaraženost istog dijela krošnje se povećava sa porastom prečnika stabala (debljinske klase) što bi moglo ukazivati na postepeno širenje poluparazita i „premještanje“ iz viših dijelova krošnje u niže. U odjeljenju 181, ova pravilnost je narušena, vjerovatno posljednjim sječama. Indikativno je, u tom pogledu, da je zaraženost donje trećine krošnje kod stabala četvrte debljinske klase značajno visoko 
ocijenjena sa indeksom 2 , uz jaču zaraženost i preostalih dijelova krošnje, a da je zaraženost svih dijelova krošnje pete debljinske klase značajno manja. krošnje.

Istraživani objekti se međusobno razlikuju prema pojavi imele u donjoj trećini

U jako napadnutih stabala imela uzrokuje neekonomičnu potrošnju vode što rezultira njihovom dehidratacijom i postepenim sušenjem. Upravo, oduzimanjem vode i mineralnih materija imela primarno slabi vitalnost domaćina. Stabla jače napadnuta imelom podložna su napadu sekundarnih biotičkih i abiotičkih štetnih agenasa. Primarno štetno dejstvo i drugih vrsta imele koje rezultira umanjenjem vitalnosti i pogoršanjem općeg zdravstvenog stanja domaćina potvrđeno je rezultatima drugih autora. 